\title{
Influence of some major genes on growth traits of local pullets in humid tropical environment
}

\author{
Oke, U. K., \\ Department of Animal Breeding and Genetics, College of Animal Science and Production, \\ Michael Okpara University of Agriculture, Umudike, Umuahia, Abia state, Nigeria \\ Email dumukal@yahoo.com
}

\begin{abstract}
A total of 210 day-old local chickens generated from a main cross and reciprocal crossing of local chickens possessing some major genes (naked-neck $(\mathrm{Na})$, frizzle $(\mathrm{F})$ and normal feathered gene (na) were used to evaluate the growth characteristics of the pullets in a randomized complete block design. The genetic groups produced were homozygous naked neck, $\mathrm{Na} / \mathrm{na}$ and frizzle $(\mathrm{F} / \mathrm{Na})$, reciprocal naked neck $(\mathrm{Na} / \mathrm{F})$ and frizzle $(\mathrm{F} . / \mathrm{Na})$ and normal feathered (na/na) chickens. There was a significant difference $(p<0.05)$ in mean daily feed intake at week 8 , with the $\mathrm{Na} / \mathrm{F}$ genotypes consuming more than other groups. Mean body weight gain and feed conversion ratio did not differ among all the genetic groups. Results indicate that the F/F genotype had significantly $(\mathrm{p}<0.05)$ highest mean day-old body weight $(30.90 \pm 2.73 \mathrm{~g})$, highest mean body weigh at sixteen $(442.50 \pm 6.61 \mathrm{~g})$ and twenty four weeks $(114.00 \pm 32.99 \mathrm{~g})$ of age. The growth rate of frizzle genotypes in all combinations ( $F / F, F / N a, F / n a)$ were significantly $(p<0.05)$ higher than both naked neck homozygous and heterozygous ( $\mathrm{Na} / \mathrm{Na}, \mathrm{Na} / \mathrm{na}$ ) and normal (na/na crosses when compared. The coefficient of determination (R2) of $F$ genes $(97.4,84.40,92.90)$ were high and compared favorably with other genetic groups indicating that $F$ genes highly contributed to significant rates of growth of frizzle crosses. The na/na individuals survived most and had significantly least mortality compared to other genetic groups. This result depicts the frizzle genotype as a fast growing indigenous chicken which may be involved in breeding for developing native foundation stock for production of meat type chicken in the humid tropics.
\end{abstract}

Keywords; Major genes, growth traits, indigenous layers, humid tropics,

\section{INTRODUCTION}

The indigenous chickens of Nigeria consist of various unimproved sub-populations of heterogeneous characteristics, not yet classified into breeds and varieties since they do not share common ancestry, breed through to type and have no clear plumage colours (Obioha, 1992, Ibe, 2001). They generally have small body and egg size (Nwosu and Omeje, 1985) compared to their exotic counterparts. They are hardy and generally reported to adapt favourably to the local environment (Ikeobi, and Godwin, 1990). The chickens are flighty in nature, resistant to some diseases and parasites and lay eggs within relatively thick eggshell (Peters et al., 2007).

Despite their non-resistant and mongrel nature, there exist strains or inbred lines (Ibe, 1998) within the native chicken populations which have definite genetic constitutions. Based on this, the Nigerian local chickens can be grouped into various genotypes or genetic groups having identifiable genes of direct and indirect effect on production and quantitative trait loci (Fayeye et al., 2006). These genes called advantageous genes complexes, major genes (Ibe and Nnorom. 1999) or plumage reducing genes which include the naked-neck (Na) and Frizzle (F). These genes are associated with heat tolerance and possess productive adaptability (Horst, 1988). A study by Ojo (2003) reveals that the indigenous poultry industry falls short of its aim of self-sufficiency in animal protein consumption in the country that is put at $5 \mathrm{gm} /$ caput per day which is far cry from FAO recommended level of $35 \mathrm{gm} /$ caput. These statistics indicates that there exists an inalienable inequality between the Nigerian human population which grows astronomically and that of poultry. Genetic and phenotypic heterogeneity have been observed to exist in the domestic chickens. This diversity, which constitutes genetic resource, informs the reason for incorporating the local chicken into breeding 
programmes aimed at producing an indigenous meat breed adapted to the tropical environment.

Consequent upon their thermoregulatory functions, the plumage reducing genes have been found relevant in the tropics. The relevance is based on the restriction and structure of the feather of naked neck and frizzle chickens. For instance, the naked-neck genes have been found to cause $30-40 \%$ reduction in feather coverage (Ngenga, 2005). The advantage of these genes over their normally feathered counterparts in a hot humid environment is in terms of feed intake, growth rate (Deeb and Cahaner, 1994) and weight gain (Yalcin et al., 1997). The local chickens are generally unimproved and as such their growth rates are relatively low compared to the improved ones. There extensive mode of production and limited research on the birds combine to aggravate the difficulty encountered in assessing their growth performance in terms of feed intake and feed conversion ratio. Carel et al (1982) observed that whereas chickens maintained in the cool room attained greater live weight than chicken in the hot room, the reverse was the case in the hot room. This indicates that the thermoregulatory function of the naked neck and frizzle genes may be well utilized in hot environment. The study was therefore undertake to determine the influence of some major genes on growth characteristics of crossbred local chickens and to establish the genotypes with the best performance for selection for further improvement.

\section{MATERIALS AND METHODS}

The experiment was conducted at the Poultry unit, Teaching and Research farm, Michael Okpara University of Agriculture, Umudike located on latitude $05^{\circ} \mathrm{C} 29 \mathrm{~N}$ and longitude $07^{\circ} 33^{\prime}$ East. It is approximately $122 \mathrm{~m}$ above sea level. Umudike has a maximum and minimum daily temperature of $27^{\circ} \mathrm{C}$ $36^{\circ} \mathrm{C}$ and $20-26^{\circ} \mathrm{C}$ respectively with relative humidity of $57-91 \%$ and annual rainfall of $2177 \mathrm{~mm}$. The high climatic factors make this environment significant to animal production.

Breeding procedure: $A$ base population of 180 local chickens consisting of 10 naked neck males, 50 naked neck females, 10 frizzle males, 50 frizzle females, 10 frizzle males, 50 frizzle females, 10 normal males, and 50 normal feathered female obtained from the Teaching and Research farm, Michael Okpara University of Agriculture, Umudike. The birds were randomly selected and moved into deep litter pens and mating was in the ratio of 1:4. The entire mating scheme resulted in 3 homozygous and two heterozygous main crosses, each of naked neck and frizzle, 2 reciprocal crosses between naked neck and frizzle and one main crosses of normal as shown in Table 1.

Table 1 Mating scheme of the base population for the production of F1 crossbred local chickens

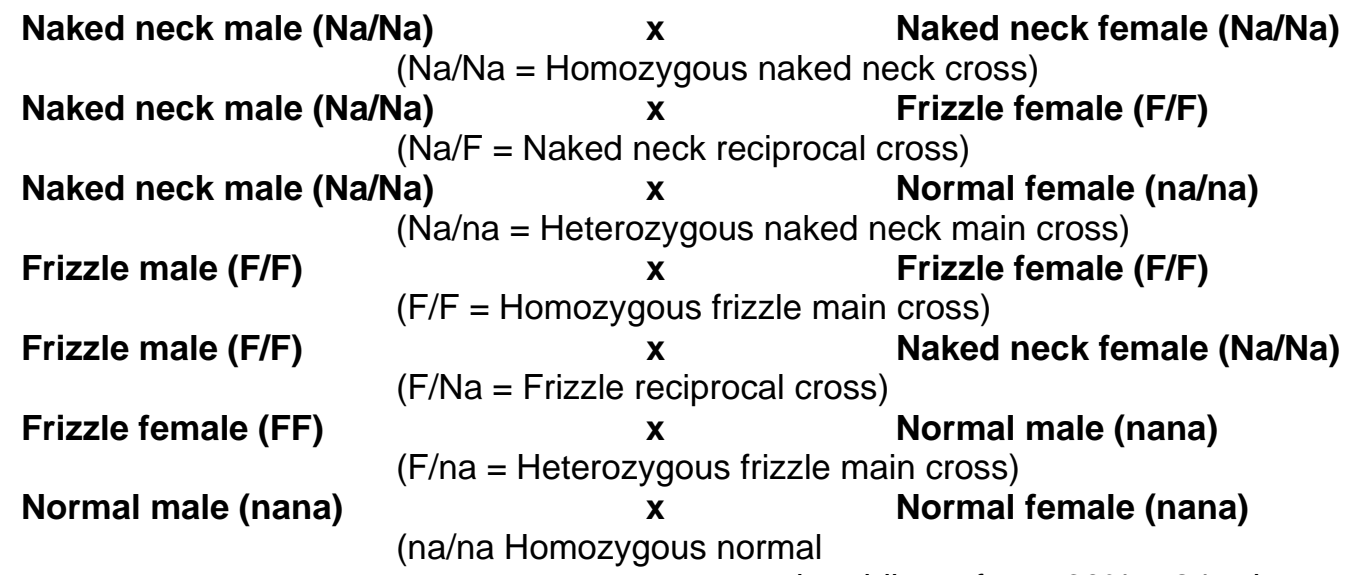

humidity of $55-60 \%, 24$ days to hatching, the

The hens after being mated produced fertile eggs which were identified and set in a western type cabinet incubator. Incubation and hatchery condition were $0-23$ days, temperature $99.8^{\circ} \mathrm{F}$ and relative temperature was $98^{\circ} \mathrm{F}$ and relative humidity of $98 \%$. A total of 400 day-old crossbred local chicks were produced.

Management of crossbred local chickens: The chicks were brooded for the first five weeks of life 
under continuous illumination. Thereafter they were raised on the deep litter under natural light. Each genotype groups were randomly selected and kept in an open-sided deep litter with 40 birds per genotype group having 3 replicates of 13 birds per subgroup. The pullets were fed growers mash containing $2700 \mathrm{kcal} / \mathrm{kg} \mathrm{ME}$ and $16 \% \mathrm{CP}$ and the birds had access to feed and water ad-libitum.

The initial mean body weight of the chicks were determined at day-old and subsequently mean body weight (MBW) were measured weekly using a top loading scale. Weight gain was determined as the difference between body weights of a present week from body weight of a former week. Mean daily feed intake, feed conversion ratio and mortality were also determined. Growth rate was determined from the regression analysis of mean body weight on age using the regression coefficient. Data collected from the study were subjected to analysis of variance in a randomized complete block design with genetic group as treatment and hatch as blocks. SPSS (2004) and Genstat (2007) computer application programmes were used for the analysis. The model of the design is shown below.

$\mathrm{Y}_{\mathrm{ijk}}=\mu+\mathrm{B}_{\mathrm{i}}+\mathrm{G}_{\mathrm{j}}+\mathrm{E}_{\mathrm{ijk}}$

Where $Y_{\mathrm{ijk}}=k^{\text {th }}=$ observation of the $j^{\text {th }}$ genetic group

$\mu=$ population mean

$\mathrm{B}_{\mathrm{i}}=$ Effect of the $\mathrm{i}^{\mathrm{th}}$ hatch

$\mathrm{G}_{j}=$ Effect of $j^{\text {th }}$ genetic group

$E_{\mathrm{ijk}}=$ Random error, assumed to be independently, identically and normally distributed with zero mean homogenous variance.

Mean with significant difference were separated using least significant difference at 0.05 level of probability. Simple linear regression analysis was used to determine the growth rates of the genetic groups. The regression model used is shown below:

$W_{i}=a+b(\text { Age })_{i}+E_{i j}$

Where

$\mathrm{W}_{\mathrm{i}}=$ the $\mathrm{i}^{\text {th }}$ body weight $(\mathrm{g})$

$\mathrm{a}=$ regression constant

$\mathrm{b}=$ the required growth rate

$\mathrm{e}_{\mathrm{ij}}=$ random error, which was assumed to be independently, identically and normally distributed with zero mean and homogenous variance.
The estimated rates were statistically compressed using t-statistic as provided by the group regression analysis carried out with Genstat computer application programme.

\section{RESULTS AND DISCUSSION}

The mean day-old body weight (MDBW), mean body weight MBW and mean body weight gain (MBWG) are shown in Table 2. There were significant difference $(p<0.05)$ in the MDBW of the genetic groups, with homozygous frizzle (FF) and heterozygous frizzle (F/na0 crosses having the highest value of $30.90 \pm 2.73$ and $30.75 \pm 1.82$ respectively. This significant difference in the MDBW suggests that frizzle $(F)$ gene may have the potential for fast growth, considering that they had the highest initial day-old weight. This genetic potential for growth was evident as from week 16 when F/F individual attained significant $(p<0.05)$ heavier mean body weight (MBW) than their counterparts. There were no significant $(p<0.05)$ difference at week 4, 8 and 12 for MBW of the genotypes. The delay in the manifestation of difference in MBW until week 16 may be due to the fact that divergent significant growth among different breeds, strains or genotypes of chickens is mostly observed in their life time as they approach sexual maturity (Ibe, 19933, Peter et al 2007).

The mean body weight values obtained in this study fall within the range of values reported for the Nigerian local chicken in previous study by Payne (1990), Ibe (1993), Fayeye et al (2005). This observation shows that the indigenous chicken is a small sized poultry. Reduction in body size is very important from the point of view of lower maintenance, requirement and greater efficiency of thermoregulation and has informed the use of the sex-linked dwarf genes (dw) which causes 20-30\% reduction in size in poultry improvement programme (Ibe 1993). 
Agric. Biol. J. N. Am., 2011, 2(4): 570-576

Table 2 Influence of some major genes on body weight (g) and body weight gain (g) of crossbred local chickens at growing phase (0-24 weeks of age)

\begin{tabular}{|l|l|l|l|l|l|l|l|l|}
\hline & \multicolumn{9}{|c|}{ Mean of genetic group } \\
\hline $\begin{array}{l}\text { Age } \\
\text { (Weeks) }\end{array}$ & $\begin{array}{l}\text { Parameter } \\
(\mathbf{g})\end{array}$ & $\mathbf{N a / N a}$ & $\mathbf{N a / F}$ & $\mathbf{N a} / \mathbf{n a}$ & $\mathbf{F / F}$ & F/Na & F/na & Na/na \\
\hline $\mathbf{0}$ & MDBW & $27.53^{\mathrm{ab}}$ & $27.19^{\mathrm{ab}}$ & $24.42^{\mathrm{bc}}$ & $30.90^{\mathrm{a}}$ & $25.88^{\mathrm{bc}}$ & $30.75^{\mathrm{a}}$ & $22.3^{\mathrm{c}}$ \\
\hline & & 2.22 & 0.28 & 1.26 & 2.73 & 0.61 & 1.82 & 2.05 \\
\hline $\mathbf{4}$ & MBW & 105.50 & 104.01 & 105.84 & 129.15 & 119.91 & 117.73 & 101.44 \\
\hline & & 11.97 & 12.29 & 14.71 & 10.89 & 12.93 & 10.12 & 14.73 \\
\hline & MBWG & 10.66 & 17.83 & 14.25 & 18.32 & 21.73 & 20.31 & 18.20 \\
\hline & & 4.62 & 3.24 & 8.82 & 9.06 & 7.93 & 11.15 & 7.31 \\
\hline $\mathbf{8}$ & MBW & 208.80 & 249.23 & 216.10 & 260.27 & 216.52 & 241.07 & 184.83 \\
\hline & & 12.88 & 19.85 & 11.30 & 22.28 & 17.40 & 44.31 & 15.30 \\
\hline & MBWG & 18.72 & 57.30 & 25.52 & 67.03 & 37.22 & 23.40 & 13.48 \\
\hline & & 11.90 & 11.93 & 23.28 & 38.61 & 12.79 & 15.30 & 8.59 \\
\hline $\mathbf{1 2}$ & MBW & 381.65 & 405.30 & 328.75 & 442.50 & 389.10 & 390.70 & 333.50 \\
\hline & & 20.86 & 50.50 & 20.77 & 6.61 & 36.76 & 33.88 & 21.53 \\
\hline & MBWG & 44.42 & 34.40 & 47.75 & 38.88 & 43.50 & 46.37 & 47.20 \\
\hline & & 12.13 & 20.42 & 7.79 & 3.31 & 10.30 & 6.12 & 6.65 \\
\hline $\mathbf{1 6}$ & MBW & $580.00^{\mathrm{bc}}$ & $635.50^{\mathrm{ab}}$ & $477.67^{\mathrm{c}}$ & $714.00^{\mathrm{a}}$ & $580.00^{\mathrm{bc}}$ & $602.2^{\mathrm{abc}}$ & $485.20^{\mathrm{bc}}$ \\
\hline & & 17.89 & 70.88 & 34.52 & 15.03 & 51.65 & 47.65 & 29.63 \\
\hline & MBWG & 39.40 & 41.05 & 28.84 & 48.60 & 36.70 & 10.88 & 40.38 \\
\hline & & 14.62 & 12.44 & 8.30 & 9.42 & 11.24 & 10.88 & 10.94 \\
\hline $\mathbf{2 4}$ & MBW & $875.80^{\mathrm{b}}$ & 957.00 & $796.50^{\mathrm{b}}$ & $1143.0^{\mathrm{a}}$ & $938.00^{\mathrm{b}}$ & $885.50^{\mathrm{b}}$ & $785.50^{\mathrm{b}}$ \\
\hline & & 24.35 & 98.53 & 47.03 & 32.99 & 100.33 & 40.78 & 53.40 \\
\hline & MBWG & 19.10 & 33.33 & 18.50 & 35.00 & 30.00 & 41.00 & 21.70 \\
\hline & & 6.18 & 18.72 & 14.13 & 14.05 & 10.37 & 19.39 & 3.66 \\
\hline
\end{tabular}

${ }^{a-c}$ Means in the same row with different superscripts are significantly different $(p<0.05)$

standard errors underneath the values

MDBW = Mean day-old body weight $(\mathrm{g})$

MBW = Mean body weight

MBWG = Mean body weight gain (g)

There were no significant difference $(p>0.05)$ in mean body weight gain (MBWG) among all the genetic groups in all the weeks. This observation however, was not consistent with the findings of Chineke (2001) who observed that most genes that influence rapid growth in farm animals also affect weight gain positively. The major setback encountered in the improvement of the indigenous chicken is their poor genetic profile (Oluyemi 1978) which is due mainly to lack of purposeful selection of the local chicken unlike their exotic counterparts (Kitalyi 1998, Nwalusanye, 1998). This could explain the reason for lack of this difference in weight gain since the breeding strategies employed have involved only the local chicken. To improve weight gain of these chickens, crossbreeding may be considered promising.

The mean daily feed intake (MDFI) and feed conversion ratio (FCR) of the crossbred local chickens are presented in Table 2. Apart from the

MDFI which showed a significant difference $(p<0.05)$ at week 8 , there were no significant difference $(p>0.05)$ in MDFI and FCR in all the weeks. The highest $(p>0.05)$ feed consumption obtained for the reciprocal $\mathrm{Na} / \mathrm{F}$ genes could be partly due to the combining effect of the two major genes in breeding who beneficial influence had been reported by Yunus and Cahaner (1999) as coming from efficiency of thermoregulation imparted by the two genes, $\mathrm{Na}, \mathrm{F}$ and partly due to maternal influence of the frizzle dam $\mathrm{Na} / \mathrm{F}$, thus supporting the observation that chicken tend to be influenced by their dam origin. The lack of significant difference $(p>0.05)$ in FCR throughout the growing phase indicates that these chickens were poor converters of feed. Significant difference may be obtained following a long term selection within the existing population (Ibe 1978) or crossbreeding using highly productive exotic birds Cahander (1994). The mortality observed was generally not significant in all the genetic groups except for the $\mathrm{F} / \mathrm{Na}, \mathrm{Na} / \mathrm{Na}$ genotypes. The reason could be attributed to the observed reduced liveability (hatchability) and fitness in naked neck and frizzle 
chicken (FAOCDR, 1998, Horst, 1989). The bare and the recoiled skin of naked neck and frizzle chicken may be a disadvantage to them during their early stage of life and to forestall this enough heat should be supplied to them and perhaps brooding period lengthened to check the early mortalities.

Table 3 shows the regression of body weight on age of the genetic groups. The growth rates of the 7 genetic groups were $40.45,20.07,35.08,51.80$, $42.37,40.23$ and 35.53 . The growth rate indicates the change in body weight caused by unit change in age. The growth rates of frizzle genotypes in all combination (FF, F/Na and F/na) where significantly $(p<0.05)$ higher than both naked neck homozygous and heterozygous ( $\mathrm{Na} / \mathrm{Na}, \mathrm{Na} / \mathrm{na}$ ) and normal (na/na) crosses when compared together. The frizzle gene $(F)$ is among the plumage reducing genes identified by Horst (1988), which has the ability to confer fast growth on chicken due to its ability to facilitate convection on the individual, thus enabling it for better feed conversion and hence faster growth as noted in this study. The coefficients of determination $\left(R^{2}\right)$ were high and compared favourably with other genetic groups, indicating that $F$ genes highly contribute to significant rates of growth of frizzle crosses. Growth rate is important characteristics of growing animals. The greatest rate of growth in the life time of the animal is attained at the point of inflection which corresponds to the age at sexual maturity (Gille, 2004). It therefore, follows that animals with greater rate of growth tend to reach sexual maturity earlier and may have higher average daily gain since the relative accuracy of regression of weight on time as an estimate of absolute growth rate has been found to compare with average daily gain (Liu et al 1991).

Table 3 Influence of some genes on mean daily feed intake (g), feed conversion ratio and mortality of the crossbred local chickens

\begin{tabular}{|c|c|c|c|c|c|c|c|c|}
\hline & \multicolumn{8}{|c|}{ Mean of genetic group } \\
\hline $\begin{array}{l}\text { Age } \\
\text { (Weeks) }\end{array}$ & $\begin{array}{l}\text { Parameter } \\
\text { (g) }\end{array}$ & $\mathrm{Na} / \mathrm{Na}$ & $\mathrm{Na} / \mathrm{F}$ & $\mathrm{Na} / \mathrm{na}$ & F/F & $\mathrm{F} / \mathrm{Na}$ & F/na & $\mathrm{Na} / \mathrm{na}$ \\
\hline \multirow[t]{4}{*}{4} & MDFI & 15.07 & 14.86 & 15.12 & 18.45 & 17.13 & 29.02 & 14.49 \\
\hline & & 1.71 & 1.76 & 2.10 & 1.56 & 1.85 & 13.11 & 2.10 \\
\hline & FCR & -0.23 & 6.31 & 9.98 & 1.79 & 8.31 & 23.67 & 11.17 \\
\hline & & 8.00 & 0.97 & 8.09 & 3.45 & 2.85 & 13 & 5.89 \\
\hline \multirow[t]{4}{*}{8} & MDFI & $30.93^{\mathrm{ab}}$ & $34.20^{\mathrm{a}}$ & $25.33^{\mathrm{C}}$ & $32.13^{\mathrm{ab}}$ & $31.52^{\mathrm{ab}}$ & $30.32^{a b}$ & $27.70 b^{c}$ \\
\hline & & 1.67 & 1.74 & 0.96 & 2.92 & 2.98 & 3.89 & 1.64 \\
\hline & FCR & 7.38 & 4.20 & 6.90 & 8.79 & 22.59 & 13.85 & 14.46 \\
\hline & & 5.81 & 1.43 & 2.62 & 6.25 & 17.64 & 8.59 & 4.76 \\
\hline \multirow[t]{4}{*}{12} & MDFI & 35.05 & 43.75 & 31.61 & 43.48 & 42.01 & 39.97 & 40.47 \\
\hline & & 3.85 & 8.00 & 2.43 & 2.65 & 3.06 & 4.60 & 4.55 \\
\hline & FCR & 7.72 & 6.28 & 4.98 & 7.96 & 8.77 & 6.01 & 6.32 \\
\hline & & 2.76 & 4.01 & 0.67 & 0.61 & 2.42 & 1.10 & 0.76 \\
\hline \multirow[t]{4}{*}{16} & MDFI & 50.77 & 57.37 & 50.16 & 58.59 & 57.96 & 57.96 & 48.13 \\
\hline & & 5.20 & 8.03 & 0.16 & 8.33 & 2.09 & 3.13 & 4.01 \\
\hline & FCR & 17.31 & 13.26 & 8.81 & 10.43 & 16.27 & 13.73 & 10.21 \\
\hline & & 5.50 & 3.94 & 2.95 & 2.77 & 4.32 & 2.83 & 1.89 \\
\hline \multirow[t]{6}{*}{24} & MDFI & 53.62 & 61.45 & 50.68 & 64.40 & 55.88 & 61.19 & 49.28 \\
\hline & & 3.70 & 8.71 & 2.90 & 5.57 & 3.28 & 2.48 & 6.31 \\
\hline & FCR & 61.69 & 6.35 & 10.90 & 19.65 & 21.65 & 14.21 & 19.32 \\
\hline & & 42.65 & 4.18 & 6.49 & 5.49 & 6.41 & 8.12 & 3.24 \\
\hline & $\begin{array}{l}\text { Mortality (\%) } \\
\text { (0-24ks) }\end{array}$ & $61.67^{\mathrm{abc}}$ & $43.14^{\mathrm{abc}}$ & $42.8^{\mathrm{abc}}$ & $68.33^{\mathrm{ab}}$ & $70.88^{a}$ & $29.33^{b c}$ & $24.00^{c}$ \\
\hline & & 16.16 & 8.60 & 13.24 & 9.30 & 9.59 & 13.72 & 11.22 \\
\hline
\end{tabular}

${ }^{a-c}$ Means in the same row with different superscripts are significantly different $(p<0.05)$

standard errors underneath the values

$\mathrm{MDFI}=$ Mean daily feed intake $(\mathrm{g})$

$\mathrm{FCR}=$ Feed conversion ratio 
Table 4 Growth rates of the crossbred local chickens at growing phase (0-24 weeks of age)

\begin{tabular}{|l|l|l|l|l|}
\hline $\begin{array}{l}\text { Genetic } \\
\text { group }\end{array}$ & Equation $^{\mathrm{a}}$ & $\mathbf{R}^{2}$ (\%) & $\mathbf{S . ~ E}$ & $\begin{array}{l}\mathbf{t}_{\text {pro }} \\
\mathbf{0}^{\mathbf{b}}\end{array}$ \\
\hline $\mathrm{Na} / \mathrm{Na}$ & $\begin{array}{l}\mathrm{W}= \\
75.93+40.45 \mathrm{~A}\end{array}$ & 97.00 & 49.64 & \\
\hline $\mathrm{Na} / \mathrm{F}$ & $\begin{array}{l}\mathrm{W}= \\
15.96+20.07 \mathrm{~A}\end{array}$ & 88.20 & 108.88 & 0.079 \\
\hline $\mathrm{Na} / \mathrm{na}$ & $\begin{array}{l}\mathrm{W}= \\
58.41+35.08 \mathrm{~A}\end{array}$ & 94.00 & 62.06 & 0.558 \\
\hline F/F & $\begin{array}{l}\mathrm{W}= \\
109.13+51.80 \mathrm{~A}\end{array}$ & 97.40 & 58.98 & 0.001 \\
\hline F/Na & $\begin{array}{l}\mathrm{W}= \\
83.42+42.37 \mathrm{~A}\end{array}$ & 87.40 & 112.27 & 0.057 \\
\hline F/na & $\begin{array}{l}\mathrm{W}= \\
62.72+40.23 \mathrm{~A}\end{array}$ & 62.90 & 77.55 & 0.003 \\
\hline na/na & $\begin{array}{l}\mathrm{W}= \\
63.44+35.55 \mathrm{~A}\end{array}$ & 92.40 & 70.98 & 0.950 \\
\hline
\end{tabular}

*All individual regressions are significant $(p<0.001)$

$\mathrm{W}=$ Body weight $(\mathrm{g})$

$A=$ Age (weeks)

R2 = Coefficient of determination (\%)

$\mathrm{SE}=$ Standard error of the estimate

$\mathbf{t}_{\text {pro } 0.05}=$ Significance of t-statistic obtained when the regression estimates were statistically compared by the technique of grouped simple linear regression

CONCLUSION: The result indicates that the frizzle homozygous main cross manifested the greatest growth characteristics in terms of body weight changes and growth rate. This is an indication that the frizzle gene may have the potential for the development of meat-type chicken since fast growth or heavy body weight is an important attributes of a broiler chicken. This potential of $F$ gene may be exploited through selection and crossbreeding.

\section{REFERENCES}

Cahaner, A (1994) Poultry improvement: Integration of present and new genetic appearance for broilers: In Proc. $5^{\text {th }}$ World congress on genetics applied to livestock production on Canada. Pp 25-32.

Carol, J. Hanzl, Somes J. R (1982) The effect of naked neck gene, $\mathrm{Na}$, on growth and carcass composition of broilers raised in two temperatures. Poultry sci. 62: 934-941

FAOCDR (1988) Village chicken production system in rural Africa-household food security and gender issues, Food and Agriculture Organization Co-operative Document Repository. http/www.fao.org/docrep/003

Fayeye, T. R., Adeshiyan, A. B., Olugbami, A. A (2005) Egg traits, hatchability and early growth performance of the Fulani-ecotype chicken. Livestock Research for Rural Development 17 (8) 1-7

Fayeye, T. R., Ayorinde, K. L., Ojo, V., Adesina, D. M (2006) Frequency and influence of show major genes on body weight and body size parameters of Nigerian local chickens. Livestock Research and Rural $\begin{array}{llll}\text { Development } & 18 & \text { (37) } & \text { 1-9. }\end{array}$ http/www.cipav.org.co/irrd183/faye18037.htm

Genstat (2007) Genstat discovery edition 3. Genstat release 7.2 DE ( $p c$ windows $X P$ ).

Gille, U (2004) Growth curve analysis and allometry. http:/wwwunileipzigde/-vetana/growth.htm

Horst, $\mathrm{P}$ (1988) nature of fowl as reservoir for genome and major genes with direct and indirect effects on productive adaptability. Proc. Xviii Worlds Poultry congress. Nagaga Japan. Pp 97-105

Horst, P (1989) Nature fowl as reservoir for genomes and major genes with direct and indirect effect on adaptability and their potential for tropical oriented. Breeding plans. Arch. Gefluglla pp 63-69.

Ibe S. N, Nwosu, U. F (1999) Influence of naked neck and frizzle genes on early growth of chickens in a tropical environment. Proc. $26^{\text {th }}$ NSAP Ann. Conf. 21-25 March. Unilorin, Ilorin Nig. K. Joseph et al (eds) pp 296-295.

Ibe, S. N (1993) Growth performance of normal, frizzle and naked neck chickens in a tropical environment. Nig. J. Anim prod 20:25-31

Ibe, S. N (1995) Repeatability of growth traits in Nigeria local chickens using early records. Nig. J. Anim. Prod 21 (1) 5-9

Ibe, S. N (1998) An introduction to genetics and animal breeding $\left(1^{\text {st }}\right.$ ed) Longman Nigeria Plc. Ikeja

Ibe, S. N (2001) Problems and proposal of developing Nigerian poultry breeds. J. sc Agric. Food. Tech and Envt 1: 1-3

Ikeobi, C. O. N, Godwin, V. A (1999) Presence of the polydactyl gene in the Nigerian local chickens. Tropical J. Anim sci. 1: 57-65.

Kitalyi, A. J. (1998) Village chicken production systems in rural Africa household food security and gender issues. FAO Animal Production and Health paper. 142 Rome $\quad \mathrm{pp} 81$. http/www.fao.org/docrep/003/w8989e/w8989e00.htm

Mwalusanya, N. A (1998) Productivity and nutritional studies of local chickens under village management 
Agric. Biol. J. N. Am., 2011, 2(4): 570-576

conditions. Unplished MSc Dissertation. Royal Veterinary and Agriculture, University. Copenhagen Denmark. Pp 56

Njenga, S. K (2005) Productivity and socio-cultural aspect of local poultry phenotypes in coastal Kenya pp 1-28.

Nwachukwu, E. N., Ibe, S. N, Ejekwu, K, Oke, U. K (2006) Evaluation of growth parameters of main and reciprocal crossbred normal, naked neck and frizzle chickens in a humid tropical environment. J. Anim Ansnet Adv 5(7) 542-546

Nwosu, C. C, Omeje, S. S (1985) Short-term egg production parameters of the local chicken and its F1 crosses with gold-link under two different housing types. E. Afri Agric for J. 51: 49-53.

Obioha, F. C (1992) A guide to poultry production in the tropics $\left(1^{\text {st }}\right.$ ed) Enugu Atena Publishers

Ojo, S. O (2003) Productivity and technical efficiencies of poultry egg production in Nigeria. Int $\mathrm{J}$. of poultry sci 2(6) $459-464$
Oluyemi, J. A (1979) Selection of the Nigerian indigenous fowl for 12-week body weight. J. Anim prod 11: 199202.

Payne, W. J. A (1990) An introduction to animal husbandry in the tropics $\left(4^{\text {th }}\right.$ ed) Longman group Ltd.

Peters, S. O., Ikeobi, C. O. N., Ozoje, M. O. Famakinwa, O. A (2007) Egg quality of Nigerian local chicken as influenced by some major genes. N. J. Anim. Prod. 34 (1) 25-35.

SPSS (2004) Statistical package for social sciences SPSS Inc 13.0 for windows.

Yaccin, S. A., Testik, S. Oikan, S. Satter, P. Celen, F., Cahaner, A (1997) Performance of naked neck and normal broilers in hot warm and temperate climates. Poult Sc. 76: 930-937.

Yunis, R., Cahaner, A (1999) Effect of the naked neck (Na) and frizzle ( $F$ ) genes on growth and meat yield of broilers and their interaction with ambient temperature and potential growth rates. Poult sci. 78: 1347-1352. 